\title{
Quantitative Measurement of "Natural" and Immunization-induced Haemophilus influenzae type b Capsular Polysaccharide Antibodies
}

\author{
John B. Robbins ${ }^{[43]}$, J. C. Parke, Jr., Rachel Schneerson, and John K. Whisnant \\ Developmental Immunology Branch, National Institute of Child Health and Human Development, Bethesda, Maryland, and the Charlotte \\ Memorial Hospital, Charlotte, North Carolina, USA
}

\begin{abstract}
Extract
Haemophilus influenzae type $b$ antibodies were measured quantitatively in normal and immunized humans and in commercially available pooled immunoglobulin. A "protective" serum level was estimated to be 0.06 to $0.1 \mu \mathrm{g}$ antibody/ml based upon the anti-type $b$ concentration in normal adult sera and pooled immunoglobulin. An age-related difference characterized the adult and infant serum antibody response to injection of the purified type $b$ capsular polysaccharide. The adults responded with higher and sustained antibody levels than the infants and children. An immunized infant reacted with type $b$ antibody formation after nasopharyngeal carriage of $H$. influenzae type $b$ and two infants reacted with type $b$ antibodies after enteric carriage of Escherichia coli with a cross-reacting antigen.

Speculation

Qualitative and quantitative differences characterize the adult versus the infant reresponse to the capsular polysaccharide of $H$. influenzae type $b$. This age-related difference in the serum anti-type $b$ antibody response may be due to the development of differentiated cells induced by whole bacteria, either as $H$. influenzae type $b$ or by other organisms with cross-reacting antigens. The "protective" level of serum anti-type $b$ antibodies, estimated by two methods, was achieved by immunization of infants, which suggests that this procedure may confer protective immunity.
\end{abstract}

\section{Introduction}

Most invasive diseases caused by $H$. influenzae are caused by type $b$ organisms and occur during infancy and early childhood $[1,6,7,25,30,31,34]$. Our decision to study the induction of type $b$ serum antibodies in infants was based upon evidence suggesting that the capsular antigen is important in the acquisition of immunity to this organism. The evidence for the protective nature of anticapsular antibodies may be sum- marized as follows: ( 1 ) of the six $H$. infuenzae capsular types, type $b$ causes almost all invasive diseases (meningitis, epiglottitis, osteomyelitis, etc.) $[1,6,7,25$, $30,31,34] ;(2)$ the protective effect of hyperimmune animal serum is type specific, as shown by the loss of its activity following absorption with the type $b$ capsular polysaccharide $[17,22,28]$; (3) the inverse relationship between the age incidence of $H$. influenzae type $b$ meningitis and the prevalence of serum antibacterial antibodies parallels the age-related development 
of anti-type $b$ antibodies as measured by passive hemagglutination $[7,30]$; (4) individuals with X-linked hypogammaglobulinemia are susceptible to severe and repeated attacks of $H$. influenzae type $b$ meningitis [28]; passive immunization of these individuals with pooled immunoglobulin shown to contain anti-type $b$ antibodies confers a high degree of protection against invasive diseases caused by this organism [30]; (5) "acute" serum samples from patients with $H$. influenzae type $b$ diseases showed no detectable serum antitype $b$ antibodies [30]. After convalescence, most individuals developed serum antibodies [22, 23, 30].

Normal adults, with pre-existing serum anti-type $b$ antibodies, who received injections of the purified $H$. influenzae type $b$ polysaccharide responded with a prompt and sustained serum antibody response [4, 30]. These volunteers showed no untoward reactions. Our preliminary studies of the serum antibody response of infants and children showed lower antibody levels than those observed in adults. Previous studies utilized passive hemagglutination to assay anticapsular antibodies [30] which was capable of detecting approximately $0.2-0.5 \mu \mathrm{g} / \mathrm{ml}$ antibody as estimated by comparing the endpoint titration of a human and a rabbit serum with their concentration of precipitating antibody. Approximately the same amount of serum antibody was detected by the complement-dependent bactericidal reaction. These methods have two serious limitations at low levels of antibody. The first is that the antibody concentration is expressed as an endpoint titration of a series of doubling dilutions. The second is that the complement-dependent bactericidal reaction may be induced by noncapsular $H$. influenzae antibodies [21, 23].

In this study, a newly developed radioimmunoassay has provided a quantitative method to characterize the adult and infant human serum antibody response to injection of the $H$. influenzae type $b$ capsular polysaccharide.

\section{Materials and Methods}

\section{Radioimmunoassay}

An ${ }^{125}$ I derivative of the $H$. influenzae type $b$ capsular polysaccharide was prepared by a modification of the method proposed by Gotschlich [3]. Two milliliters of $H$. influenzae type $b$ (strain "Rab") polysaccharide $(5.0 \mathrm{mg} / \mathrm{ml})$ [10], were brought to $\mathrm{pH} 10.0$ with constant stirring. Cyanogen bromide $\left(50 \mathrm{mg} / \mathrm{ml} \mathrm{H}_{2} \mathrm{O}\right)$ [36] was added (0.1 $\mathrm{mg} \mathrm{CNBr} / \mathrm{mg}$ polysaccharide) and the $\mathrm{pH}$ maintained at 10.0 with $0.1 \mathrm{~N} \mathrm{NaOH}$ for $1 \mathrm{hr}$ at room temperature by addition of $0.1 \mathrm{~N} \mathrm{NaOH} .{ }^{14} \mathrm{C}$ labeled tyramine (specific activity $1 \mu \mathrm{Ci} / \mathrm{mg}$ ) [37] in 0.5 $\mathrm{M} \mathrm{NaHCO}_{3}$ was added and the reaction was continued for $1 \mathrm{hr}$ at room temperature and for $15 \mathrm{hr}$ at $4^{\circ}$. The reaction mixture was centrifuged at $65,000 \times g, 4^{\circ}$ for $2 \mathrm{hr}$, and the supernatant passed through a column $(2.5 \times 30 \mathrm{~cm})$ of Sephadex G-25 equilibrated with phosphate-buffered saline, $\mathrm{pH}$ 7.4. The molar ratio of tyramine to polysaccharide in the tyrosylated derivative as determined by ${ }^{14} \mathrm{C}$ to pentose was approximately $8 / 1$. This product was radiolabeled with $2 \mathrm{mCi}$ ${ }^{125} \mathrm{I}$ by the iodine monochloride method [27]. The specific activity of several iodinated derivatives varied from 70,000 to $90,000 \mathrm{cpm} / \mu \mathrm{g}$.

An adult serum ( $S K$ immunized with $50 \mu \mathrm{g}$ of the purified polysaccharide) was used as a reference standard. The antibody concentration of this serum was determined by quantitative precipitation analysis [17]. The reaction mixture consisted of $2.0 \mathrm{ml}$ of $S K$ serum previously heated to $56^{\circ}$ for $30 \mathrm{~min}$ and dilutions of the type $b$ polysaccharide. After incubation at $37^{\circ}$ for $30 \mathrm{~min}$ and for $48 \mathrm{hr}$ at $4^{\circ}$, the precipitates were collected by centrifugation, washed twice with phosphate-buffered saline $\mathrm{pH} \mathrm{7.2,} \mathrm{and} \mathrm{then} \mathrm{dissolved} \mathrm{in}$ $0.8 \%$ sodium lauryl sulfate. Assuming an extinction coefficient $(280 \mathrm{~nm})$ for human immunoglobulin of 14.0 , the antibody $(\mathrm{Ab})$ content of the reference serum was found to be $40 \mu \mathrm{g} \mathrm{Ab} / \mathrm{ml}$.

Fetal calf serum [38], assayed for the absence of $\gamma$ globulin by cellulose acetate electrophoresis, was used to dilute the reference standard $(S K)$ and other serum samples with high antibody levels. A $50-\mu \mathrm{l}$ serum sample and $10 \mu 1{ }^{125} \mathrm{I}$ antigen were delivered to a Microfuge tube [39]. The tubes were capped and mixed, incubated at $37^{\circ}$ for $30 \mathrm{~min}$ and overnight at $4^{\circ}$. Sixty microliters of saturated ammonium sulfate were added; tubes were mixed and then centrifuged for 5 min [39]. Fifty $\mu$ l of the supernatant were removed and counted for two minutes in an auto-gamma counter [40]. The maximum ${ }^{125} \mathrm{I}$ antigen-binding capacity of the undiluted reference serum for the ${ }^{125 I}$ polysaccharide was $90-95 \%$ and this value was adjusted to $100 \%$ in the standard curves (Fig. 1). Curves were constructed for these concentrations of antigen and dilutions of the reference serum. The antigen concentration of $0.1 \mu \mathrm{g} / \mathrm{ml}$ was chosen because most adult preimmune sera bound $31-90 \%$ of the antigen. Serum samples that had less than $30 \%$ binding were assumed to contain less than $0.04 \mu \mathrm{g} \mathrm{Ab} / \mathrm{ml}$. The coefficient of variation for the assay was $10 \%$ at $7.0 \mu \mathrm{g} \mathrm{Ab} / \mathrm{ml}$ and 
$7 \%$ at $0.8 \mu \mathrm{g} / \mathrm{ml}$. The antibody concentrations are expressed as micrograms of $\mathrm{Ab}$ per milliliter, but were converted to logrithms to normalize the data for statistical analysis. Postimmunization antibody levels were compared with preimmune levels by paired $t$ tests.

\section{Antigen for Immunization}

$H$. influenzae type $b$ capsular polysaccharide, prepared by a modification of a previously published method [10], was dissolved in phosphate-buffered saline or precipitated from $0.05 \mathrm{~m}$ sodium acetate on 2 $\mathrm{mg}$ aluminum hydroxide.

\section{Bacteriologic}

$H$. influenzae type $b$ and bacteria possessing antigens cross-reacting with type $b$ capsular polysaccharide were sought in nasopharyngeal and rectal cultures using the antiserum-agar technique $[17,27,41]$.

\section{Results}

\section{Anti-type $b$ Antibodies of Pooled Human Immuno- globulin (Cohn Fraction II)}

To estimate the minimal protective level of serum anti-type $b$ antibody, the serum concentration of passively administered antibodies in patients with $\mathrm{X}$ linked hypogammaglobulinemia was determined. Published values for the catabolic rate $\left(t_{1 / 2}=20\right.$ days $)$ and extracellular equilibration (40\%) of immunoglobulin were used to predict the serum antibody concentration 3 weeks after injection [5, 8]. Analysis of 86 commercially available human immunoglobulin preparations, including hyperimmune tetanus antitoxin and pertussis globulin, showed an average level of $39 \mu \mathrm{g}$ type $b$ antibody $/ \mathrm{ml}$ immunoglobulin (range 20-73). Assuming an immunoglobulin dose of $0.05-0.1 \mathrm{ml} / \mathrm{kg}$ injected every 3 weeks, the average serum anti-type $b$ antibody level prior to the next injection of immunoglobulin was calculated to be $0.12-0.24 \mu \mathrm{g} \mathrm{Ab} / \mathrm{ml}$. Patients receiving $0.05 \mathrm{ml} / \mathrm{kg}$ (low dose) of immunoglobulin containing $20 \mu \mathrm{g} \mathrm{Ab} / \mathrm{ml}$ (lowest concentration) would have about $0.06 \mu \mathrm{g} \mathrm{Ab} / \mathrm{ml}$. Based upon these calculations, we have estimated the minimal protective level of anti-type $b$ antibodies to be $0.06-0.1 \mu \mathrm{g} \mathrm{Ab} / \mathrm{ml}$.

\section{"Natural" Anti-type b Antibodies in Normal Adults}

The mean anti-type $b$ antibody concentration in sera of 422 normal adult blood bank donors of the Clinical Center of the NIH and from 100 pregnant women at term at the Jacoby Hospital at the Albert

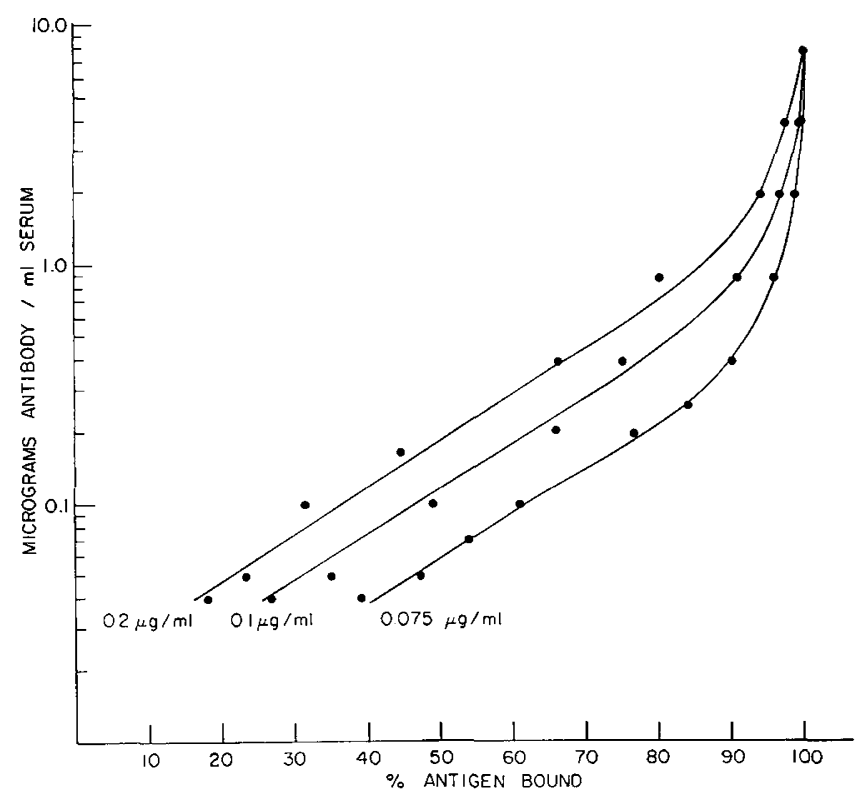

Fig. 1. The percentage of binding of a reference serum (SK immunized with $50 \mu \mathrm{g}$ type $b$ polysaccharide) with three concentrations of ${ }^{125}$ I tyraminated derivative of Haemophilus influenzae type $b$ polysaccharide is shown. The concentration of anti-lype $b$ antibody in the reference serum was measured by its concentration of precipitating antibody.

Einstein College of Medicine, Bronx, N.Y. and the 20 adult volunteers prior to immunization was $1.39 \mu \mathrm{g}$ $\mathrm{Ab} / \mathrm{ml}(\mathrm{SD}=3.02$, range 0.04-26.0). Ninety-five percent of the adults had anti-type $b$ antibody levels greater than $0.04 \mu \mathrm{g} \mathrm{Ab} / \mathrm{ml}$. Since most adults are protected against $H$. influenzae type $b$ disease and since the mechanism of protection is presumed to be serum antibody, then the protective level may be estimated to be $0.04-$ $0.1 \mu \mathrm{g} \mathrm{Ab} / \mathrm{ml}$.

\section{Serum Antibody Response of Adult Volunteers Immu- nized with type b Polysaccharide}

As previously reported, immunization of 20 adult volunteers with $50 \mu \mathrm{g} \mathrm{H}$. influenzae type $b$ polysaccharide resulted in increase of the pre-existing serum antibodies within 3 weeks [30]. Sera from these adults were re-examined by the radioimmunoassay with additional samples obtained from 19 volunteers 3.5 years later.

Table I shows that all adults had detectable pre-immunization anti-type $b$ antibodies $(0.04-1.8 \mu \mathrm{g} \mathrm{Ab} / \mathrm{ml})$. The 3-week, 3-month, and 3-year levels were greater than the pre-immune levels $(P<0.0005)$. There was no statistically significant difference between the 3week postimmune levels and levels at 3 months and 3 years $(P<0.5)$. There was a wide variation in the 
Table I. Serum antibody response of adult volunteers receiving injections of $50 \mu \mathrm{g}$ Haemophilus influenzae type $b$ capsular polysaccharide

\begin{tabular}{ccccc}
\hline \multirow{2}{*}{ Subject } & \multicolumn{4}{c}{ Anti- $t$ ype $b$ antibody in serum, $\mu \mathrm{g} / \mathrm{ml}$} \\
\cline { 2 - 5 } & Preimmune & 3 weeks & 3 months & 3 years \\
\hline 1 & 0.04 & 1.4 & 2.0 & 6.0 \\
2 & 0.07 & 1.7 & 1.5 & 2.8 \\
3 & 0.08 & 3.2 & 2.8 & 3.2 \\
4 & 0.10 & 0.4 & 1.1 & 1.1 \\
5 & 0.11 & 1.2 & 1.2 & 1.2 \\
6 & 0.12 & 22.0 & 20.0 & 20.0 \\
7 & 0.15 & 1.7 & 1.8 & 2.2 \\
8 & 0.15 & 30.0 & 30.0 & 18.0 \\
9 & 0.20 & 1.8 & 1.8 & 0.9 \\
10 & 0.25 & 40.0 & 41.8 & 39.2 \\
11 & 0.40 & 0.7 & 0.8 & 2.3 \\
12 & 0.58 & 18.0 & 32.0 & 5.4 \\
13 & 0.58 & 9.3 & 21.8 & 39.0 \\
14 & 0.68 & 0.8 & 0.8 & 1.3 \\
15 & 0.80 & 15.0 & 15.0 & 5.4 \\
16 & 0.80 & 50.0 & 50.0 & 41.8 \\
17 & 0.90 & 1.5 & 4.0 & V.N.A.2 \\
18 & 1.70 & 65.0 & 65.0 & 15.0 \\
19 & 1.70 & 14.0 & 14.0 & 19.5 \\
20 & 1.80 & 40.0 & 40.0 & 12.0 \\
Avg. & 0.56 & 15.88 & 17.37 & 12.43 \\
sD & 0.576 & 19.36 & 19.60 & 13.88 \\
\hline
\end{tabular}

1 The subjects were ranked according to the preimmune serum antibody levels.

2 Volunteer not available.

maximum level of the serum antibodies after immunization $(1.1-65.0 \mu \mathrm{g} \mathrm{Ab} / \mathrm{ml})$. The postimmunization level seemed to be related to the preimmunization level of serum anti-type $b$ antibodies as the average postimmune level of the five volunteers with the lowest preimmune levels was 2.86 and for the five with the highest was $22.1 \mu \mathrm{g} \mathrm{Ab} / \mathrm{ml}$.

\section{Immunization of Infants and Children}

The parents of patients infirmed at the Holy Angels Nursery, Belmont, N.C., were requested permission to have their children participate in the immunization program. Of 63 parents queried by a letter, 43 responded affirmatively. The first 40 affirmative letters were numbered consecutively and randomly assigned to one of four groups which received 10 or 50 micrograms of the polysaccharide injected subcutaneously or intradermally. All of the patients in the nursery were examined by one of us $(J C P)$. Nasopharyngeal and rectal cultures, urinalysis, complete blood count, and blood for antibody assay were taken 2 days before immunization. Rectal temperatures were recorded before and 6-8 hr after injection of the polysaccharide. A complete blood count and urinalysis including urine culture were taken in the afternoon and the following morning. A blood sample for antibody analysis was taken from all the children 3 weeks and 2 months after injection.

No toxic effects of injection of the $H$. influenzae type $b$ polysaccharide were observed as measured by a febrile response, elevated peripheral white blood count, or abnormal urinary sediment. One individual developed a temperature of $101^{\circ}$ the following morning accompanied by signs and symptoms of an upper respiratory infection.

$H$. influenzae type $b$ was not recovered from any of the cultures. Eight bacteria cross-reacting with $H$. influenzae type $b$ were recovered from the stool cultures. Three of these were bacillus species, one was a Streptococcus viridans, three were Staphylococcus aureus, coagulase positive, and one was an E. coli 075: Kf147:H5 (strain Easter) [13, 35].

Table II summarizes the results of immunization of these infants and children. Not shown was a plot of the preimmune levels against age which showed significant curvature with a maximum at 5.7 years. The relationship between antibody level and age can be described by the equation $y=-3.528+0.956 X-$ $0.0835 X 2$ where $y$ is age in years and $X$ is $\log (\mathrm{Ab})$. The controls differed slightly from the four experimental groups as their average age ( 5.75 years) was greater and their preimmune antibody level $(0.90 \mu \mathrm{g}$

Table II. Serum antibody response of infants and children receiving injections of

Haemophilus infuenzae type $b$ polysaccharide

\begin{tabular}{|c|c|c|c|c|c|c|}
\hline \multicolumn{3}{|c|}{ Group } & \multirow{2}{*}{$\frac{\text { Age }}{(\text { Years } \pm \mathrm{sD})}$} & \multicolumn{3}{|c|}{ Antibodies in serum $( \pm \mathrm{SD}), \mu \mathrm{g} / \mathrm{ml}$} \\
\hline$\underset{\mu \mathrm{g}}{\text { Antigen dose, }}$ & $\begin{array}{l}\text { Route of } \\
\text { injection }\end{array}$ & $\begin{array}{l}\text { No. of } \\
\text { subjects }\end{array}$ & & Preimmune & 3 weeks & 2 months \\
\hline 50 & i.c. & 10 & $4.1 \pm 2.7$ & $0.37 \pm 0.25$ & $3.10 \pm 4.55$ & $1.91 \pm 3.75$ \\
\hline 50 & s.c. & 8 & $4.3 \pm 3.1$ & $0.17 \pm 0.21$ & $3.91 \pm 4.63$ & $3.09 \pm 3.40$ \\
\hline 10 & i.c. & 12 & $3.9 \pm 3.0$ & $0.57 \pm 0.61$ & $6.24 \pm 5.50$ & $2.85 \pm 3.77$ \\
\hline 10 & s.c. & 10 & $4.9 \pm 1.7$ & $0.34 \pm 0.41$ & $3.52 \pm 3.54$ & $2.43 \pm 3.72$ \\
\hline Control subjects & & 18 & $5.8 \pm 2.6$ & $0.90 \pm 1.59$ & $1.27 \pm 2.19$ & \\
\hline
\end{tabular}


$\mathrm{Ab} / \mathrm{ml}$ ) was higher than the control subjects. On the average, the control subjects showed an increase of $0.37 \mu \mathrm{g} \mathrm{Ab} / \mathrm{ml}$ during the first 3 weeks $(P<0.034)$. In view of this finding, the changes in the four experimental groups were compared to the change in antibody levels of the controls.

All experimental groups responded with statistically significant antibody formation 3 weeks after immunization. The highest 3-week level was in the group receiving $10 \mu \mathrm{g}$ intracutaneously $(P<0.001)$. No consistent effect of the route of immunization was observed, as the intracutaneous route was more effective at the $10 \mu \mathrm{g}$ dose and the subcutaneous route was more effective at the $50 \mu \mathrm{g}$ dose. The $10 \mu \mathrm{g}$ dose seemed to be more effective in that only 1 out of 20 failed to respond with more than a twofold increase in serum antibody as compared with 7 non-responding subjects out of 20 injected with $50 \mu \mathrm{g}$.

Ten of the 40 infants and children receiving injections had less than $0.04 \mu \mathrm{g} \mathrm{Ab} / \mathrm{ml}$ before immunization. Only one of these children with undetectable preimmunization levels failed to respond with antibody formation. In contrast to the serum antibody response of the adults, the level in these infants and children declined within 2 months.

A slight increase in the serum anti-type $b$ antibody levels was observed in the group which did not receive injections (control subjects). Several of the children in this group had bacteria with cross-reacting antigen to the $H$. influenzae type $b$ capsular polysaccharide which may have been the cause of their response.

\section{Immunization of 2-to 3-Month-Old Infants}

Based upon the previous results, an experiment was designed to test the effect of two antigen dosages, 5.0 and $10 \mu \mathrm{g}$, and the possible adjuvant effect of aluminum hydroxide upon the immune response of 2- to 3-month-old infants. All the infants were born at Charlotte Memorial Hospital, Charlotte, N.C., and were examined at 4 days of age and during their visits to the well baby clinic for physical examination and immunizations. During these visits nasopharyngeal and rectal cultures were studied for $H$. influenzae and for bacteria with antigens cross-reactive with type $b$ capsular polysaccharide. The infants were injected at 2 to 3 months of age with $0.5 \mathrm{ml}$ subcutaneously in the deltoid region. Blood samples were taken from the infants at each visit and from the mother at the time of immunization. No untoward effects of the immunization such as fever were reported to us by the parents. One infant developed a nonindurated erythematous reac- tion for 2 days at the site of the injection of $10 \mu \mathrm{g}$ of the alum preparation.

The results from the 23 infants receiving injections were compared with serum antibody levels in 90 infants, 3 to 10 months old, examined at the Charlotte Memorial Hospital for routine medical care. The serum anti-type $b$ antibodies and the results of the nasopharyngeal and rectal cultures of the immunized infants is shown in Figure 2. Whereas 67 of 90 nonimmunized infants had undetectable antibody, only 3 of the 23 continued to have undetectable antibody through 3,10 , and 11 months after immunization $(T J$, $D F$, and $D M$, respectively). Of these three infants, the maternal level was $8.2 \mu \mathrm{Ab} / \mathrm{ml}$ in one and 0.04 or less in the other two. Two of the five infants receiving injections of $10 \mu \mathrm{g}$ in saline did not develop detectable antibody.

The kinetics of the serum anti-type $b$ antibody formation in the responding infants could be assessed only in a rough fashion. Thirteen of the immunized infants had increased serum anti-type $b$ antibodies at the time of their next clinic visit. Six infants $(A A, L W$, $D B, A P, L A$, and $D C$ ) responded only after 2-3 months. In two infants, $A P$ and $D C$, with high pre-existing serum antibodies, it was difficult to assess the onset of their serum antibody formation. In three infants the serum anti-type $b$ antibody level declined to

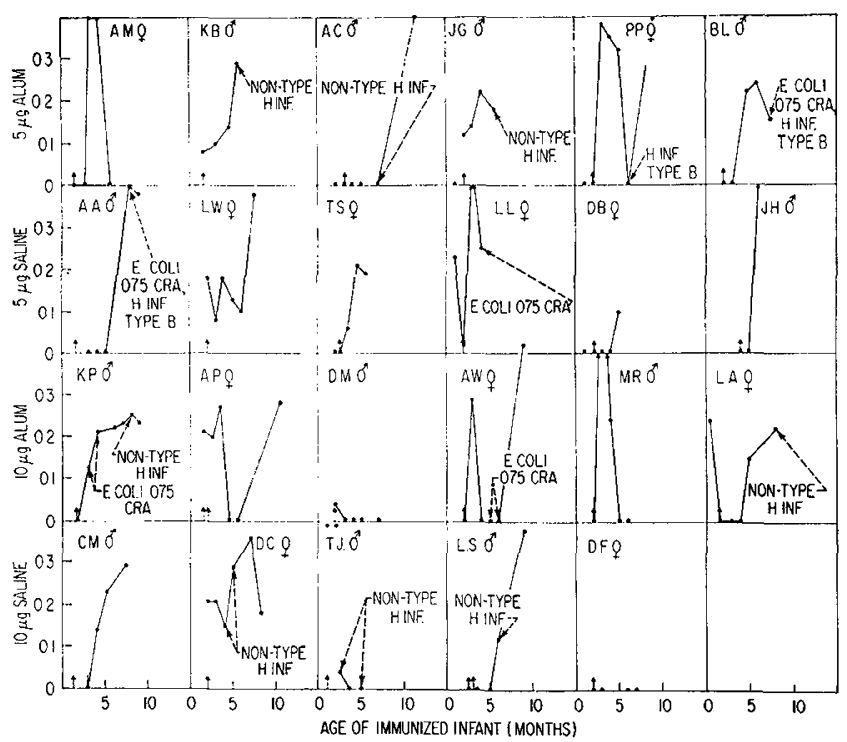

Fig. 2. The serum anti-type $b$ antibodies of 23 normal infants who received injections at 2-3 months of age is shown. The date on which the infants received injections of type $b$ polysaccharide is shown by the arrow and the detection of Haemophilus influenzae type $b$ and nontypeable organisms or Escherichia coli with a cross-reacting antigen from nasopharyngeal and rectal cultures is shown. 
below $0.1 \mu \mathrm{g} \mathrm{Ab} / \mathrm{ml}(P P, M R$, and $A W)$. The maximum serum antibody levels observed in these three infants was higher than the average maximum titer.

The effects of dosage and aluminum hydroxide upon the serum anti-type $b$ response were compared. The highest serum antibody levels were observed in individuals receiving $5.0 \mu \mathrm{g}$ polysaccharide in saline. The group receiving $10 \mu \mathrm{g}$ in saline had 2 nonresponding infants.

Five $E$. coli with cross-reacting antigens (CRA) to the capsular polysaccharide of $H$. influenzae type $b$ were detected in the rectal cultures. All of the $E$. coli were $075: \mathrm{H} 5$ organisms. One infant $(K P, 10 \mu \mathrm{g}$ alum) had $E$. coli with the CRA 1 month after immunization. The response of this individual was characterized by a rapid rise and sustained antibody level. One infant $(A W)$ with an $E$. coli with the CRA after his level of immune serum anti-type $b$ antibody had declined to less than $0.1 \mu \mathrm{g} \mathrm{Ab} / \mathrm{ml}$, and showed a rise to $0.42 \mu \mathrm{g}$ $\mathrm{Ab} / \mathrm{ml}$ at the time of the next bleeding. One infant with nasopharyngeal $H$. influenzae type $b 2$ months after her level of immunization-induced anti-type $b$ antibodies had declined reacted with a high level of serum antibodies $(0.58 \mu \mathrm{g} \mathrm{Ab} / \mathrm{ml})$ at her clinic visit I month later. These findings suggest that $E$. coli with CRA enhances the immune response to the H. influenzae type $b$ polysaccharide [35] and that injection of the $H$. influenzae type $b$ polysaccharide does not inhibit the serum anticapsular antibody response to this bacterial antigen.

\section{Discussion}

At least three differences contrast the serum type $b$ polysaccharide antibody response of infants and children to that of adults. First, there is a longer interval to reach the maximum antibody concentration after the injection of the polysaccharide in the infants. Second, there are lower levels of postimmunization anti-type $b$ antibodies in the infants and children. Third, in contrast to the relatively constant level of anti-type $b$ antibodies observed 3-4 years after immunization of the adults, a decline from the maximum level of serum antibodies was observed in most of the infants and children within several months. Similar results were recently observed for infants and adults receiving injections of the meningococcal group $C$ polysaccharide [10] and for infants and children receiving injection of whole encapsulated Diplococcus pneumoniae types $I$ and $V I$ and Salmonellae [14,32].
The immune response elicited by the injection of the purified type $b$ capsular polysaccharide differs from that elicited by intact $H$. influenzae type $b$ injected into animals [29]. In rabbits, injection of the purified polysaccharide over a wide dosage range $(0.1-100 \mu \mathrm{g})$, either as a saline solution or adsorbed to aluminum hydroxide, does not result in an increase in serum anti-type $b$ antibodies [14]. In contrast, injection of live or formaldehyde-treated bacteria results in the rapid formation of serum anti-type $b$ antibodies. A similar immune response to isolated capsular polysaccharides as contrasted to that of encapsulated bacteria have been observed for pneumococci and meningococci in animals $[9,26]$. These observations suggest that the immunogenic properties of the isolated type $b$ polysaccharide may be compared with a hapten with the $H$. influenzae bacteria serving as a carrier molecule. Consistent with this explanation of the immunogenic properties of the type $b$ polysaccharide are the observations that the limited serum antibody response to pneumococcal polysaccharides is thymus independent and thus, the increased immune reaction elicited by the whole encapsulated bacteria is related to the carrier portion of the immunogen [15]. The thymus-related system has been postulated to regulate the immune response to the carrier portion of the immunogen and thus confer the "memory" or anamestic component [18].

The serum antibody response of adult humans elicited by the purified polysaccharide is similar to that elicited by pneumococcal, meningococcal, and other bacterial polysaccharides [11, 12, 16, 19, 33]. The rapid and sustained serum antibody formation elicited by the type $b$ polysaccharide may be due to direct stimulation of previously differentiated cells, perhaps induced by an asymptomatic $H$. influenzae type $b$ infection or by enteric and/or nasopharyngeal bacteria with antigens cross-reactive with the capsular polysaccharide. A continuous exposure to a microbial environment might explain the age-related development to the isolated capsular polysaccharide. Thus, infants would have only thymus-independent cells to react directly with the purified polysaccharide. Thymusrelated cells (carrier induced) gradually develop following contact with whole bacteria. That these mechanisms may be operative is suggested by the adult-type immune response of the three infants with fecal $E$. coli containing the cross-reactive polysaccharide as contrasted with the immunized infants and our experiments with neonatal rabbits colonized with 
cross-reacting enteric bacteria [19]. This postulated direct stimulation of previously differentiated antibodyproducing cells by the purified polysaccharide may also serve to explain the direct relation between the level of preimmune and postimmunization anti-type $b$ antibodies in the adult volunteers. This explanation, that of a low level of bacteria-induced differentiated cells, may provide a useful experimental model to study the age-related immune response observed for protein, bacterial, erythrocyte, as well as polysaccharide antigens in humans and laboratory animals [33]. It has been suggested that somatic antigens (lipopolysaccharides) may be an important stimulus for the thymus cell system. Whether the somatic antigens of $H$. influenzae type $b$ or cross-reacting gram negative enteric bacteria such as $E$. coli $075: \mathrm{H} 5: \mathrm{Kf} 147$ induces the differentiation of cells capable of synthesizing type $b$ polysaccharide antibodies or whether this differentiation may be induced by some or all lipopolysaccharides is not known [16].

The results obtained in this experiment indicate that serum $H$. influenzae type $b$ antibodies may be elicited by injection of the purified capsular polysaccharide into 2- to 3-month-old infants. Using two experimental approaches, an estimate of $0.04-0.1 \mu \mathrm{g}$ anti-type $b \mathrm{Ab} / \mathrm{ml}$ serum has been postulated to be "protective." This level of antibodies was achieved in most of the immunized infants. The exact dosage for optimum response, the mechanism of antibody formation, and the protective effect of the injection of purified polysaccharide requires further study.

\section{References and Noles}

1. Alexander, H. E.: In: R. J. Dubos, and J. G. Hirsch: Bacterial and Mycotic Infections of Man, p. 724 (J. B. Lippincott, Philadelphia, 1965).

2. Alexander, H. E., Heildelberger, M., and Leidy, G.: The protective or curative element in type b $H$. influenzae rabbit serum. Yale J. Biol. Med., 16: 425 (1944).

3. Anderson, P., Johnston, R. B., and Smith, D. H.: Human serum activities against Haemophilus influenzae type b. J. Clin. Invest., 51: 31 (1972).

4. Anderson, P., Peter, G., Johnston, R. B., Wetterlow, L. H., AND SMITH, D. H.: Immunization of humans with polyribophosphate, the capsular antigen of Haemophilus infuenzae type b. J. Clin. Invest., 51: 39 (1972).

5. Bradshaw, M. W., Schneerson, R., Parke, J. C., and Robbins, J. B.: Bacterial antigens cross-reactive with the capsular polysaccharide of Haemophilus influenzae type b. Lancet, $i$ : 1095 (1971).

6. Dawson, B., AND ZinnemanN, K.: Incidence and type distribution of encapsulated $H$. influenzae strains. British Med. J., 1 : 740 (1952).
7. Fothergill, L. D., AND WRIGHT, J.: Influenzae meningitis: The relation of age incidence to the bactericidal power of blood against the causal organism. J. Immunol., 24: 273 (1933).

8. Gitulin, D., and Janeway, C. A.: Some isotopic studies on the distribution and metabolism of plasma proteins. Advan. Biol. Med. Phys., 7: 249 (1960).

9. Gotschlich, E. C., Goldschneidfr, I., and Artenstein, M. S.: Human immunity to the meningococcus. IV. Immunogenicity of group A and group C meningococcal polysaccharides in human volunteers. J. Exp. Med., 129: 1367 (1969).

10. Gotschlich, E. C., Rey, M., Triau, R., and Sparks, K. J.: Quantitative determination of the human immune response to immunization with meningococcal vaccines. J. Clin. Invest., 51: 89 (1972).

11. Heidelberger, M.: Persistence of antibodies in men after immunization. In: A. M. Pappenhcimer: The Nature and Significance of the Antibody Response, p. 90. (Columbia University Press, New York, 1953).

12. Heidelberger, M., Macleod, C. M., Kaiser, S. J., and Robinson, B.: Antibody formation in voluntecrs following injection of pneumococci or their type-specific polysaccharides. J. Exp. Med., 82: 303 (1946).

13. Heidelberger, M., and MacPherson, C. F.: Quantitative microestimation of antibodies in the sera of man and other animals. Science, 97: 405 (1943).

14. Hones, H. L., Ziegl.er, J. F., ANd Zepp, H. D.: Development of antibody following vaccination of infants and children against pncumococci. J. Pediat., 24: 641 (1944).

15. Humphrey, J. H., Parrot, D. M. V., and East, J.: Studies on globulin and antibody production in mice thymectomized at birth. Immunology, 7: 419 (1964).

16. JONES, J. M., AND Kind, P.: Enhancing effect of bacterial endotoxins on bone marrow cells in the immune response to SRBC. J. Immunol., 108: 1453 (1968).

17. MCFarlane, A. S.: Effective trace-labelling of proteins with iocline. Nature, 182: 53 (1958).

18. Miller, J. F. A. P., ANd Mitchell. G. F.: Thymus and antigen reactive cells. Transplant. Rev., $1: 3$ (1969).

19. Myerowitz, R. L., Handzel, Z. T., SchneERSoN, R., AND Robrins, J. B.: Induction of immunity to Haemophilus influenzae type $\mathrm{b}$ in rabbits by gastrointestinal colonization with a cross-reacting Escherichia coli. Fed. Proc., 31: (2) (1972).

20. NELSon, J. D.: The bacterial etiology and antibiotic management of septic arthritis in infants and children. Pediatrics, 50: 437 (1972)

21. NORden, C.: Variable susceptibility of Haemophilus influenzae type b strains to serum bactericidal. Proc. Soc. Exp. Biol. Med., 139: 59 (1972).

22. Norden, O. W., Melish, M., Overall, J. C., and Baum, J.: Immunologic responses to Haemophilus influenzae meningitis. J. Pediat., 80: 209 (1972)

23. Peter, G. S., Greenfield, S., Howie, V. M., and Smith, D. H.: Acquisition of type-specific antibodies following exposure to Haemophilus influenzae meningitis (Abstract). In: Proceedings of the 41st Annual Meeting, Society for Pediatric Research, p. 76, Atlantic City, N. J., April 28-May 1, 1971.

24. Prtman, M.: The actions of type specific Haemophilus influenzae antiserum. J. Exp. Med., 58: 683 (1933). 
25. Pittman, M.: Variation and type specificity in the bacterial species Haemophilus influenzae. J. Exp. Med., 53: 47 I (1931).

26. RobBins, J. B.: Unpublished observations.

27. Rodrigues, L. P., Schneerson, R., and Robbins, J. B.: Immunity to Haemophilus influenzae type b. I. The isolation and some physiochemical, serologic and biologic properties of the capsular polysaccharide of Haemophilus influenzae type b. J. Immunol., 107: 1071 (1972).

28. Rosen, F. S., And Janeway, C. A.: The gamma globulins. New Engl. J. Med., 275: 709 (1966).

29. Schneerson, R., Bradshaw, M., Whisnant, J. K., Myerowitz, R. L., Parke, J. C., ANd Robbrns, J. B.: An Escherichia coli antigen cross-reactive with the capsular polysaccharide of Haemophilus influenzae type b: Occurrence among known serotypes, and immunochemical and biologic properties of $E$. coli antisera toward $H$. influenzae type b. J. Immunol., 108: 1551 (1972).

30. Schneerson, R., Rodrigues, L. P., Parke, J. C., and Robbins, J. B.: Immunity to disease caused by Haemophilus influenzae type b. II. Specificiity and some biologic characteristics of "natural", infection-acquired and immunization-induced antibodies to the capsular polysaccharide of Haemophilus influenzae type b. J. Immunol., 107: 1081 (1971).

31. Sinclair, S. E.: Haemophilus influenzae type $b$ in acute laryngitis with bacteremia. J. Amer. Med. Ass., 117: 170 (1941).

32. Smith, R. T., Eitzman, D. V., Catlin, M. E., Wirtz, E. O., AND Miller, B. E.: The development of the immune response.
Characterization of the response of the human infant and adult to immunization with salmonella vaccines. Pediatrics, 33: 163 (1964).

33. Smrth, R. T., And Robbins, J. B.: In: R. Cooke: Developmental Aspects of Immunity, in the Biologic Basis of Pediartic Practice, p. 501. (McGraw-Hill, New York, 1968).

34. TURK, D. C., AND MAY, J. R.: Haemophilus influenzae: Its Clinical Importance, p. 24. (English Universities Press, Ltd., London, 1967).

35. Waldman, T. A., and Strober, W.: Metabolism of immunoglobulins. Progr. Allergy, 13: 1 (1969).

36. Eastman Organic Chemicals, Rochester, N. Y.

37. New England Nuclear, Boston, Mass.

38. Grand Island Biological Company, Chagrin Falls, Ohio.

39. Microfuge, Beckman Instruments, Palo Alto, Calif.

40. Nuclear-Chicago Corporation, Des Plaines, Ill.

41. E. coli possessing the cross-reacting antigen were typed by Dr. George Hermann, Enterobacteriology Unit, Center for Disease Control, Atlanta, Ga.

42. This study was supported in part by Research Contract no. 70-2294, National Institute of Child Health and Human Development.

43. Requests for reprints should be addressed to: Jorn B. RobBins, M.D., National Institutes of Health, Building 10, Room 13N240, Bethesda, Md. 20014 (USA).

44. Accepted for publication November 29, 1972. 